\title{
Sistem Pakar Diagnosa Kerusakan Mesin Sepeda Motor Transmission Automatic dengan Metode Forward Chaining Studi Kasus: AHASS 00955 Mitra Perdana
}

\author{
Imron Imron ${ }^{1^{*}}$, Miftah Nur Afidah ${ }^{2}$, M. Sinta Nurhayati ${ }^{3}{ }^{3}$ Sulistiyah ${ }^{4}$, Fatmawati $^{5}$ \\ 1,2,3,4Universitas Bina Sarana Informatika, JI Kamal Raya No. 18, Ringroad Barat, Cengkareng Jakarta Barat \\ ${ }^{5}$ STMIK Nusa Mandiri, JI Damai No. 08, Warung Jati Barat. Pasar Minggu, Jakarta Selatan \\ Correspondence e-mail: *imron.imr@bsi.ac.id, miftah@bsi.ac.id, m.sinta.stn@bsi.ac.id, sulistiyah.slt@bsi.ac.id, \\ fatmawati.fmw@nusamandiri.ac.id
}

\begin{abstract}
Abstrak. Implementasi dari Sistem Pakar Diagnosa kerusakan mesin sepeda motor merupakan solusi dari peayanan service sepeda motor pada bengkel AHASS 00955Mitra Perdana, Sistem Pakar adalah sistem yang berkaitan dengan pengetahuan yang dimiliki para ahli dan pemanfaat tekhnologi untuk menyelesaikan suatu masalah. Artikel ini, membahas tentang perancangan apliaski pembuat keputusan yang memiliki peran penting dalam proses diagnosa kerusakan mesin motor. Karena sistem yang berjalan saat ini pengguna hanya menyerahkan sepeda motor kepada teknisi. Dengan Penggunaan kecerdasan buatan berbasis komputer dapat menjadi solusi bagi masalah dalam pengambilan keputusan secara terstruktur. Perancangan sistem pakar ini dirancang menggunakan metode inferensi pelacakan kedepan (forward chaining) dan dirancang dalam bentuk website agar mempermudah pengguna dalam menggunakannnya.
\end{abstract}

Kata kunci: AHASS 00955; Artificial Intelligent; Forward Chaining; Sistem Pakar; Website

Abstract. Implementation of Expert System Diagnosis of motorcycle engine damage is a solution of motorcycle service at AHASS 00955 Mitra Perdana, Expert System is a system that is related to the knowledge possessed by experts and technology users to solve a problem. This article, discusses the design of decision-making applications that have an important role in the process of diagnosing motor engine damage. Because the system is currently running the user only hands over the motorcycle to the technician. The use of computer-based artificial intelligence can be a solution to problems in structured decision making. The design of this expert system is designed using the forward tracking inference method and is designed in the form of a website to facilitate users in using it.

Keywords: AHASS 00955; Artificial Intelligent; Expert Systems; Forward Chaining; Webs

\section{PENDAHULUAN}

Menurut Martin dan Oxman dalam (Kusrini, 2006) "Sistem Pakar adalah sistem berbasis komputer yang menggunakan pengetahuan, fakta, dan teknik penalaran dalam memecahkan masalah yang biasanya hanya dapat dipecahkan oleh seorang pakar dalam bidang tersebut". Dalam kasus ini, sistem pakar juga dapat digunakan untuk mendiagnosis kerusakan untuk kendaraan bermotor. Sistem ini akan membantu customers untuk mengetahui jenis kerusakan sepeda motor.

Saat ini sebagian besar masyarakat menjadikan sepeda motor sebagai sarana transportasi yang sangat digemari. Dengan menggunakan sepeda motor pengguna dapat menghemat waktu dan biaya.

Kendala pada pengendara sepeda motor yaitu kerusakan mesin, kerusakan mesin merupakan hal merugikan bagi pengguna. Pengendara cenderung tidak mengetahui apa penyebab dan bagian apa saja yang mengalami kerusakan.

Menurut (Welim, T.W., \& Firmansyah, 2015) "Service sering disebut dengan istilah perbaikan (jasa), pengertian dari perbaikan itu sendiri adalah usaha untuk mengembalikan kondisi dan fungsi dari suatu benda atau alat yang rusak akibat pemakaian alat tersebut pada kondisi semula".

AHASS 00955 Mitra Perdana adalah salah satu bengkel Astra Honda Service Station diantara banyaknya bengkel yang masih menggunakan sistem manual pada keluhan kerusakan mesin kendaraan bermotor. Bengkel ini memiliki jumlah kunjungan 10 sampai dengan 15 kendaraan perhari. Dalam proses penanganan kerusakan, customer masih harus menginformasikan pada bagian Service Advisor untuk hal keluhan-keluhan apa saja yang dialami.

Penyampaian informasi kerusakan secara manual, memakan waktu yang cukup lama bagi pengendara. Customer membutuhkan waktu mulai dari perjalanan menuju bengkel hlngga penyelesaian perbaikan kendaraan, Untuk menghindari hal tersebut maka bengkel memerlukan diagnosa sistem pakar kerusakan mesin dimana sistem ini akan membantu customer dalam penyampaian keluhan apa saja yang dialami.

\section{METODE PENELITIAN}

Menurut (Achmad, 2016) mengatakan bahwa: "Peramban web atau lebih dikenal dengan web browser merupakan perangkat lunak yang berfungsi untuk menerima dan menyajikan sumber informasi di internet. Mudahnya, browser digunakan untuk menampilkan hamalan-halaman web".

\section{Kecerdasan Buatan}

Menurut (Khaeruzzaman, 2018) mengemukakan bahwa: "Kecerdasan Buatan adalah salah satu cabang IImu pengetahuan berhubungan dengan pemanfaatan mesin untuk memecahkan persoalan yang rumit dengan cara yang lebih manusiawi". Kecerdasan buatan atau Artificial Intelligence bekerja dengan menerima input, diproses dan kemudian menghasilkan output, yang berupa solusi dari suatu masalah berdasarkan kumpulan 
pengetahuan yang ada. Seperti dilihat pada gambar dibawah ini:

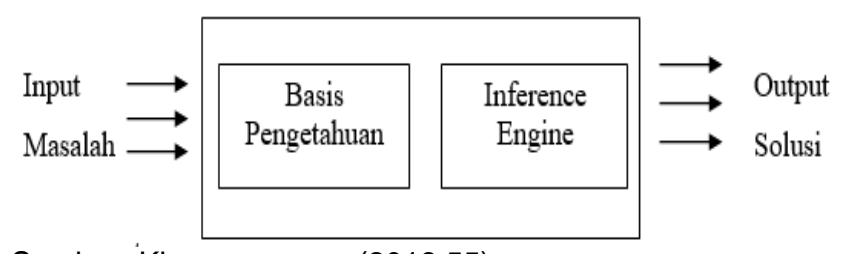

Sumber: Khaeruzzaman (2018:55)

Gambar 1. Konsep Kecerdasan Buatan di Komputer

Menurut (Khaeruzzaman, 2018) lingkup utama implementsi dalam kecerdasan buatan saat ini ditemui pada bidang-bidang berikut:

a. Sistem pakar (Expert System). Disini komputer digunakan sebagai saran untuk menyimpan pengetahuan para pakar. Dengan demikian komputer akan memiliki keahlian untuk menyelesaikan masalah dengan meniru keahlian yang dimiliki para pakar.

b. Pengolahan bahasa alami (Natural Language Processing). Dengan pengolahan bahasa alami ini diharapkan User mampu berkomunikasi dengan komputer dengan menggunakan bahasa sehari-hari. Pengenalan ucapan (Speech Recognition). pengenalan ucapan diharapkan manusia mampu berkomunikasi dengan komputer dengan menggunakan suara. Robotika dan Sistem sensor.

c. Computer vision, mencoba untuk dapat mengintrepetasikan gambar atau objek-objek tampak melalui komputer.

d. Intelligent Computer aid Instruction. Komputer dapat digunakan sebagai tutor yang dapat melatih dan mengajar.

e. Game Playing. Yaitu metode artificial intelegence yang meniru cara berfikir manusia dan game.Contohnya adalah program perfect chessmate yang mampu berfikir setara dengan grandmaster catur.

\section{Sistem Pakar}

Menurut (Kusrini, 2006) mengatakan bahwa: "Sistem pakar adalah system berbasis komputer yang menggunakan pengetahuan, fakta dan teknik penalaran dalam memecahkan masalah yang biasanya hanya dapat dipecahkan oleh seorang pakar dalam bidang tersebut". Pada dasarnya sistem pakar diterapkan untuk mendukung aktivitas pemecahan masalah, selain itu sistem pakar juga dapat berfungsi sebagai asisten yang pandai dari seorang pakar.

Adapun ciri-ciri dari sistem pakar menurut (Kusrini, 2006) adalah sebagai berikut:

1. Terbatas pada bidang yang spesifik.

2. Dapat memberikan penalaran untuk data-data yang tudak lengkap atau tidak pasti.

3. Dapat mengemukakan rangkaian alasan yang diberikan dengan cara yang dipahami.

4. Berdasarkan pada rule atau kaidah tertentu.

5. Dirancang untuk dapat dikembangkan secara bertahap.

6. Outputnya bersifat nasihat atau anjuran.

7. Output tergantung dari dialong dengan User.

\section{Knowledge base dan inference engine terpisah}

Menurut Giarrantano dan Riley dalam ((Kusrini, 2006b) arsitektur dasar dari sistem pakar dapat dilihat pada gambar berikut ini:

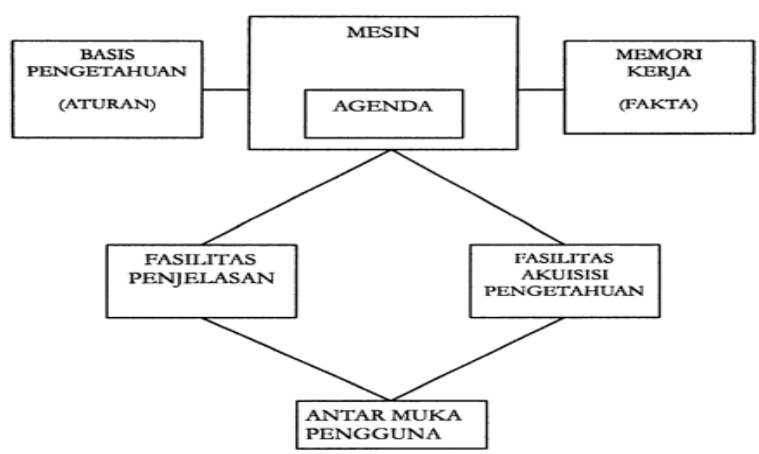

Sumber: Kusrini (2006:19)

Gambar 2. Arsitektur sistem pakar

Memori kerja dalam arsitektur sistem pakar merupakan bagian dari sistem pakar yang berisi faktafakta maslah yang ditemukan daman suatu sesi, berisi fakta-fakta tentang suatu masalah yang ditemukan dalam proses konsultasi.

\section{Mekanisme Inferensi}

Menurut Khaeruzzaman, Y. (2018) mengatakan bahwa :"Inferensi merupakan proses untuk menghasilkan informasi dari fakta yang diketahui atau diasumsikan.inferensi adalah konklusi logis (logical conclusion) atau implikasi berdasarkan pada informasi yang tersedia"

Dalam melakukan proses pengujian mekanisme inferensi mempunyai dua teknik inferensi yaitu:

1. Pelacakan ke Belakang (backward chaining)

Pelacakan kebelakang merupakan pendekatan yang dimotori oleh tujuannya (goaldriven). Dalam pendekatan ini pelacakan dimulai dari tujuan, selanjutnya dicari aturan yang memiliki tujuan untuk kesimpulannya, selanjutnya proses pelacakan menggunakan premis untuk aturan tersebut sebagai tujuan baru sebagai kesimpulannya.

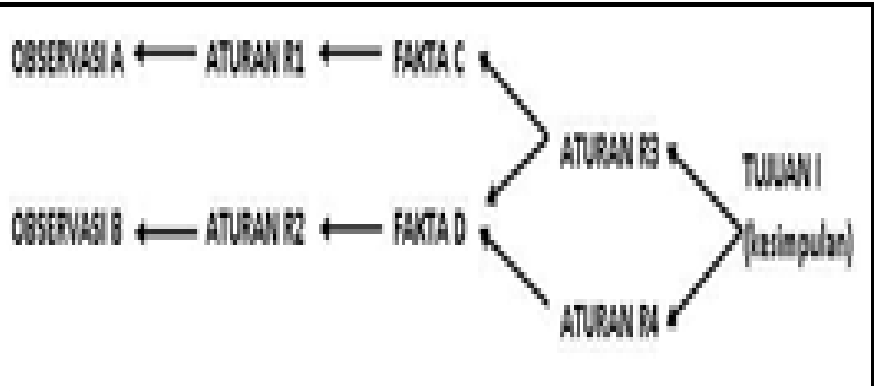

Sumber: Khaeruzzaman, $Y$

\section{Gambar 3 Backward Chaining}

\section{Pelacakan ke Depan (forward chaining)}

Pelacakan kedepan merupakan pendekatan yang dimotori data (data driven). Dalam pendekatan ini pelacakan dimulai dari informasi masukan dan selanjutnya mencoba menggambarkan kesimpulan. Pelacakan ke depan mencari fakta yang sesuai dengan bagian IF dari aturan IF-THEN. 


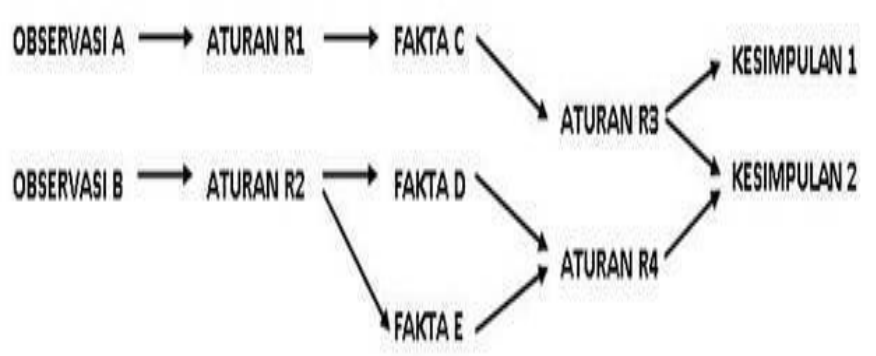

Sumber: Khaeruzzaman, $Y$

Gambar 4. Forward Chaining

\section{Konsep dasar service kendaraan}

Menurut (Welim et al., 2015) mendefinisikan bahwa "Service sering disebut dengan istilah perbaikan (jasa). Pengertian dari perbaiakan itu sendiri adalah usaha untuk mengembalikan kondisi dan fungsi dari suatu benda atau alat yang rusak akibat pemakaian alat tersebut pada kondisi semula". Adapun unsur-unsur yang terdapat pada service kendaraan yaitu:

\section{Bengkel}

Menurut (Welim et al., 2015) mengemukakan bahwa "Bengkel merupakan tempat (bangunan atau ruangan) untuk perawatan atau pemeliharaan, memperbaiki, modifikasi alat atau mesin, tempat pembuatan bagian mesin dan perakitan mesin".

\section{Motor}

Konstruksi dasar sebuah motor dapat dibagi menjadi tiga bagian utama, yaitu rangka, kelistrikan, dan mesin.

a. Bagian rangka

Berfungsi sebagai wadah penempatan mesin, sistem kelistrikan, dan penyangga penumpang.bagian dari beberapa komponen untuk menunjang agar sepeda motor dapat berjalan dan berbelok.

b. Bagian kelistrikan

Bagian kelistrikan pada sepeda motor memiliki jalur yang berbeda walaupun kelistrikan yang dihasilkan sama-sama berasal dari pembakaran mesin. Mekanisme kelistrikan dipakai untuk menghasilkan daya pembakaran untuk proses kerja mesin dan sinyal untuk menunjang keamanan berkendaraan. Bagian kelistrikan terdiri dari komponen pengapian, pengisian dan kelompok beban.

c. Bagian Mesin

Bagian mesin adalah seluruh komponen yang mengkonsumsi energi listrik selain sistem pengapian, terdiri atas system tenaga mesin. Sebagai sumber tenaga penggerak untuk berkendaraan, terdiri dari, mesin / engine, sistem bahan bakar, sistem pelumasan, sistem pembuangan, dan sistem pendinginan.

\section{Basis Data}

Menurut (Yanto, 2016) mengatakan bahwa "Basis data adalah kumpulan data yang saling berhubungan yang disimpan secara bersama sedemikian rupa dan tanpa pengulangan (redundansi), untuk memenuhu berbagai kebutuhan".

\section{Model Pengembangan Perangkat Lunak}

Menurut (A.S., Rosa \& Shalahuddin, M. 2018) mengemukakan bahwa: Model SDLC air terjun (waterfall) sering juga disebut model sekuensial linier (sequential linear) atau alur hidup klasik (classic life cycle). Model air terjun menyediakan pendekatan alur hidup perangkat lunak secara sekuensial atau terurut dimulai dari analisis, desain, pengodean, pengujian, dan tahap pendukung (support).

Berikut adalah gambar model air terjun:

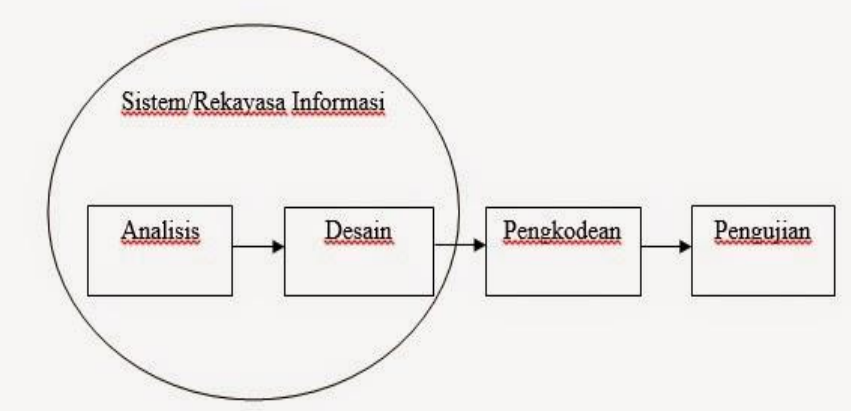

Sumber: A.S., Rosa \& Shalahuddin, M. (2018:25)

Gambar 5 Ilustrasi model waterfall

\section{Unified Modeling Language}

Menurut (A.S., Rosa \& Shalahuddin, M. 2018) mengemukakan bahwa:"UML (Unified Modeling Language) adalah salah satu standar bahasa visual yang banyak digunakan di dunia industri untuk mengidentifikasi requirement, membuat analisis \& desain, serta menggambarkan arsitektur dalam pemrograman berorientasi objek".

UML hanya berfungsi untuk melakukan pemodelan, jadi penggunaan UML tidak terbatas pada metologi tertentu, meskipun pada kenyataannya UML paling banyak diguakan pada metodologi berorientasi objek.

Macam-macam diagram UML:

\section{Activity Diagram}

Menggambarkan bagaimana alur proses dari sebuah sistem. Komponen utama dalam sebuah activity diagram adalah state dan massage. Pada tahap ini activity diagram digunakan untuk memodelkan perilaku use case object pada aplikasi yang akan dibuat.

2. Use Case Diagram

Digunakan untuk memodelkan bisnis proses berdasarkan perspektif pengguna sistem. Use case diagram terdiri atas diagram untuk use case, admin, dan User.

3. Class Diagram

Menurut (Munawar, 2005) class diagram merupakan himpunan dari objek-objek yang sejenis. Sebuah objek memiliki keadaan sesaat (state) dan perilaku (behavior). State sebuah objek adalah kondisi objek tersebut yang dinyatakan dalam attribute".

4. Squence Diagram

Aspek penting dari diagram sequence adalah bahwa hal ituadalah sebuah pesan yang digambarkan terhadap waktu. Ini berarti bahwa urutan yang tepat dari interaksi antara objek direpresentasikan langkah demi langkah. Objek yang berbeda dalam diagram 
urutan berinteraksi satu sama lain dengan mengirimkan "pesan".

\section{HASIL DAN PEMBAHASAN}

Tahapan perancangan sistem merupakan langkah-langkah untuk menentukan gambaran perangkat yang akan dihasilkan ketika pengembang melaksanakan sebuah proyek pembuatan perangkat lunak.

\section{Analisis Kebutuhan}

Analisa kebutuhan untuk sistem pakar diagnosa kerusakan motor pada bengkel AHASS 00955 Mitra Perdana diusulkan sebagai berikut:

\section{Kebutuhan Pengguna}

Kebutuhan Skenario User

A1 User dapat melakukan login setelah melakukan registrasi sebelumnya

1. Login

2. Keluar (logout)

A2 User dapat mengakses menu kamus otomotif

1. User dapat melihat gambar-gambar mesin motor

2. User mendapatkan penjelasan tentan mesin-mesin motor

A3User dapat mengakses menu konsultasi

1. Memilih sesuai keluhan yang dirasakan

2. Mengetahuibagian kerusakan

3. Mengetahui penyebab kerusakan

4. Mengetahui solusi yang di usulkan

A4User dapat melakukan daftar untuk tindakan service

1. User mengisi data diri dan kendaraan

2. User dapat daftar service

A5User dapat melihat tentang bengkel

User dapat melihat tentang sejarah dan visi misi bengkel

A6 User dapat memilih menu bantuan

User dapat melihat informasi bantuan untuk menjalankan web

\section{Kebutuhan Skenario Admin}

B1 Admin dapat melakukan login dengan akun pribadi

1. Login

2. Keluar (logout)

B2 Admin dapat melihat menu utama

B3 Admin mengelola data rule diagnosa

1. Admin dapat menambahkan rule diagnosa

2. Admin dapat menghapus rule diagnosa

3. Admin dapat mengedit rule diagnosa

B4 Admin mengelola data relasi

1. Admin dapat menambahkan relasi

2. Admin dapat menghapus relasi

3. Admin dapat mengedit relasi

B5 Admin dapat mengelola data solusi kerusakan

1. Admin dapat menambahkan solusi

2. Admin dapat menghapus solusi

\section{Admin dapat mengedit solusi}

B6 Admin dapat mengelola data kamus otomotif

1. Admin dapat menambahkan isi kamus

2. Admin dapat menghapus isi kamus

3. Admin dapat mengedit isi kamus

B7 admin dapat mengelola data admin

1. Admin dapat menambahkan data admin

2. Admin dapat menghapus data admin

3. Admin dapat mengedit data admin

B8 Admin dapat mengelola histori pendaftaran service

1. Admin dapat melihat data diri dan kendaraan pelanggan

2. Admin dapat melihat jenis kerusakan

3. Admin dapat melihat tanggal dan nomor id service

4. Admin dapat mencetak histori pendaftaran pelanggan

\section{Kebutuhan Sistem}

1. Setiap pengguna program harus melakukan login terlebih dahulu untuk menjalankan konsultasi diagnosa cara memasukan username dan password

2. Penguna sistem melakukan logout setelah menjalankan program

\section{Rancangan Diagram Use case}

Use case diagram menggambarkan fungsionalitas yang diharapkan darisebuah system. Yang dilakukan adalah "apa" yang diperbuat sistem dan bukan "bagaimana". Sebuah usecase merepresentasikan sebuah interaksi antara actor dengan system.

1. Use Case Diagram Menu User

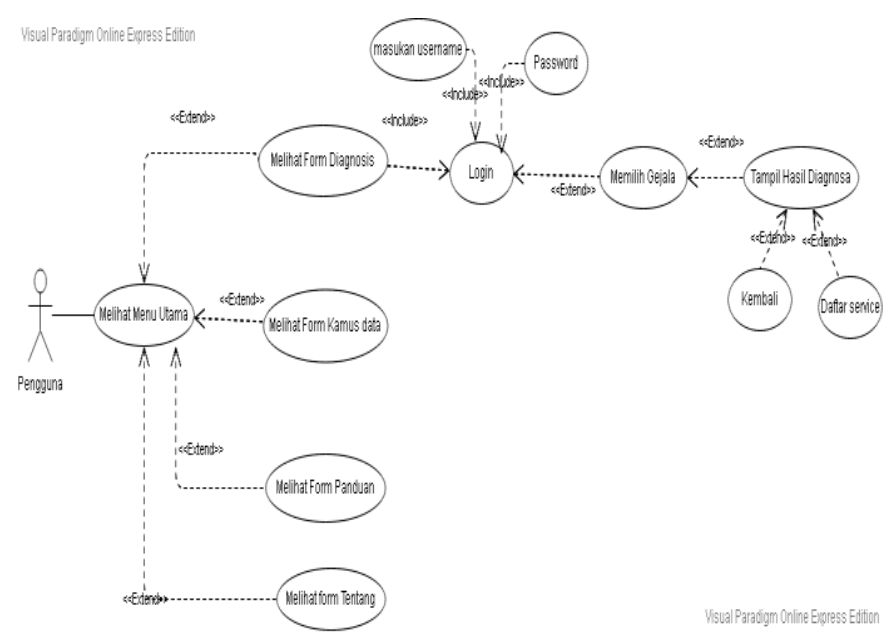

Gambar 6. Use Case Diagram Menu User

Tabel 1. Deskripsi UseCase Diagram Login User

\begin{tabular}{lll}
\hline Use Case Name & Login & \\
\hline Requirements & $\begin{array}{l}\text { A1 } \\
\text { Goal }\end{array}$ & $\begin{array}{l}\text { Pengguna dapat masuk kedalam } \\
\text { form konsultasi }\end{array}$ \\
Pre-Condition & $\begin{array}{l}\text { 1. Pengguna masuk kedalam } \\
\text { mmenu konsultasi }\end{array}$ \\
2. Pengguna registrasi terlenih \\
Post-Condition & $\begin{array}{l}\text { User melakukan konsultasi } \\
\text { diagnosa kerusakan sopeda motor }\end{array}$ \\
Failed and Condition & $\begin{array}{l}\text { Penggunagagal masuk kedalam } \\
\text { form konsultasi }\end{array}$
\end{tabular}


Primary Actors User dan Admin

Main Flow / Basic 1. User dapat melakukan login

Path 2. User memasukan Username dan password

3. User dan admin melakukan logout

Alternative Flow / A1. System rnampilkan Username Invariant A dan password salah atau tidak ada

Tabel 2 Deskripsi Use Case Diagram Halaman Pengguna

\section{Use Case Name}

Requirements

Goal

\section{Konsultasi Diagnosis}

\section{A2 - A6}

User dapat mengakses aplikasi sistem pakar

Pre-Condition User telah masuk kedalam web sistem pakar

Post-Condition

1. User mendapatkan jenis kerusakan dan solusi

2. User melakukan daftar service kendaraan

3. User dapat melihat kamus otomotif

4. User dapat melihat form panduan web

5. User dapat melihat tentang program

Failed and Condition Pengguna tidak dapat masuk kedalam web atau login

Primary Actors User

Main Flow / Basic 1. User memilih kerusakan pada Path

Alternative Flow / -

Invariant A

\section{Use Case Diagram Admin}

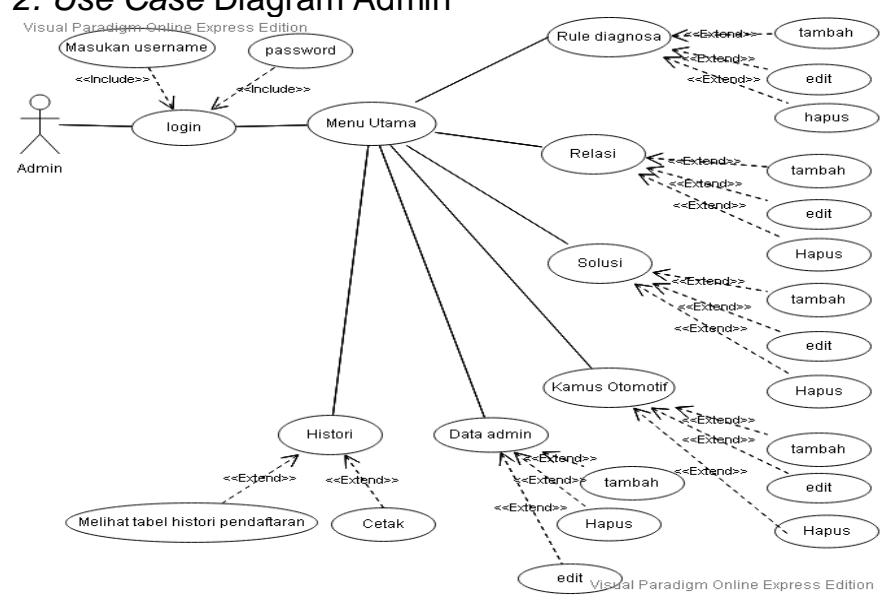

Gambar 7. Use Case Diagram Menu Admin
Tabel 3. Deskripsi Use Case Diagram Login Admin

\begin{tabular}{|c|c|}
\hline Use Case Name & Login Admin \\
\hline Requirements & B1 \\
\hline Goal & $\begin{array}{l}\text { Admin dapat masuk ke dalam } \\
\text { menu utama halaman admin }\end{array}$ \\
\hline Pre-Condition & Admin membuka aplikasi sistem \\
\hline Post-Condition & $\begin{array}{l}\text { Admin dapat melihat tampilam } \\
\text { halaman utama }\end{array}$ \\
\hline Failed and Condition & $\begin{array}{l}\text { Admin gagal masuk ke halaman } \\
\text { menu utama }\end{array}$ \\
\hline Primary Actors & Admin \\
\hline Main Flow / & 1. Admin dapat melakukan login \\
\hline Path & $\begin{array}{l}\text { 2. Admin memasukan Username } \\
\text { dan password } \\
\text { 3. Admin melakukan logout }\end{array}$ \\
\hline
\end{tabular}

Alternative Flow / A1. System rnampilkan Username Invariant A dan password salah atau tidak ada

Tabel 4 Deskripsi UseCase Diagram Relasi Halaman Admin

\begin{tabular}{|c|c|}
\hline Use case Name & Rule Diagnosa \\
\hline Requirements & B3 \\
\hline Goal & $\begin{array}{l}\text { Admin dapat menambah, mengedit } \\
\text { dan menghapus data rule diagnosa }\end{array}$ \\
\hline Pra-Condition & Admin telah login \\
\hline Post-Condotion & Tampil data rule diagnosa \\
\hline Failed and Condition & $\begin{array}{l}\text { Gagal menambah, mengedit, dan } \\
\text { menghapus data }\end{array}$ \\
\hline Primary Actor & Admin \\
\hline $\begin{array}{l}\text { Main Flow / Basic } \\
\text { Path }\end{array}$ & $\begin{array}{l}\text { 1. Admin melihat data rule } \\
\text { diagnosa }\end{array}$ \\
\hline & $\begin{array}{l}\text { 2. Admin dapat menambah data } \\
\text { rule diagnosa }\end{array}$ \\
\hline & $\begin{array}{l}\text { 3. Admin dapat menyimpan data } \\
\text { rule diagnosa }\end{array}$ \\
\hline $\begin{array}{l}\text { Alternative } \\
\text { Invariant A }\end{array}$ & $\begin{array}{l}\text { A1. Admin dapat mengubah data } \\
\text { rule diagnosa } \\
\text { A2. Admin dapatmenghapus data } \\
\text { rule diagnosa. }\end{array}$ \\
\hline
\end{tabular}

Rancangan Diagram Aktivitas

1. Activity Diagram Proses Diagnosis Customers

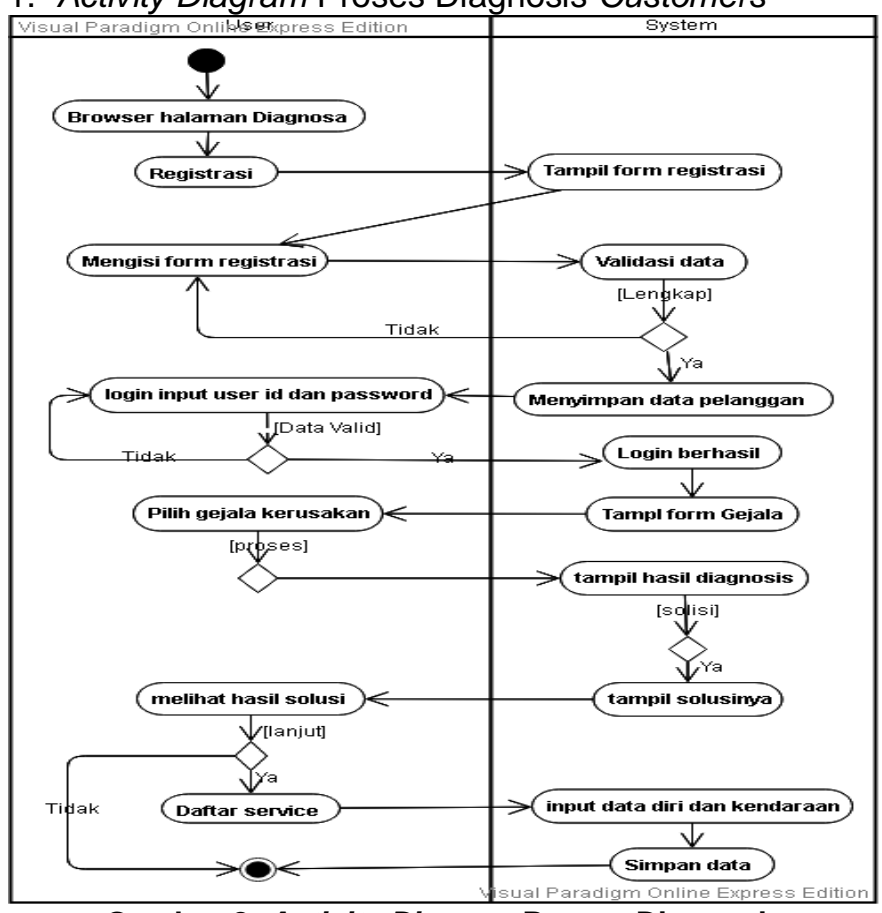

Gambar 8. Activity Diagram Proses Diagnosis 
2. Activity Diagram Login Admin

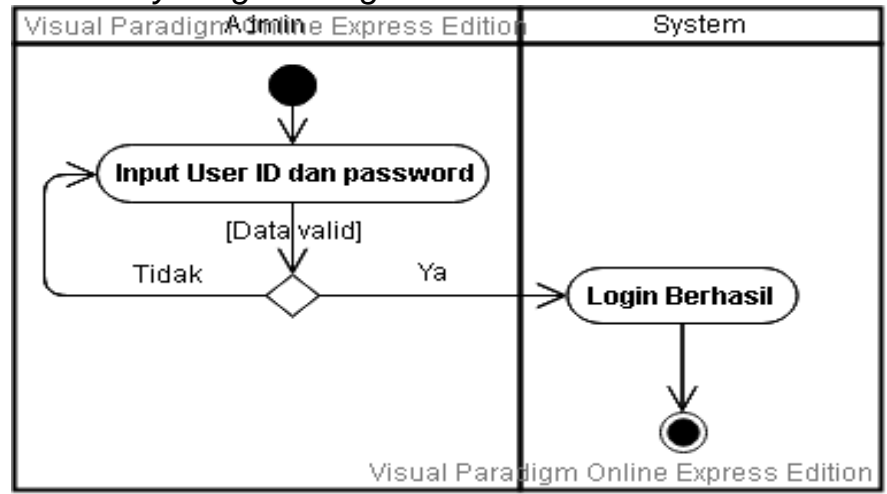

Gambar 9. Activity Diagram Login Admin

3. Activity Diagram Rule Diagnosa

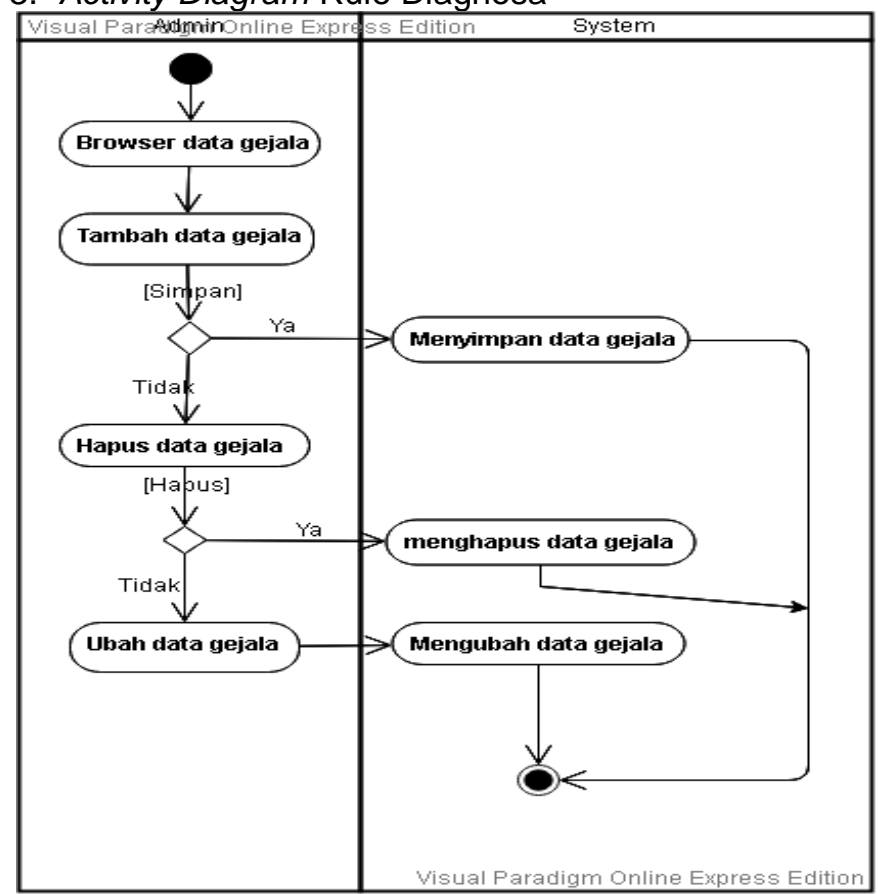

Gambar 10 Activity Diagram menu Rule Diagnosa

4. Activity Diagram Form Relasi Halaman Admin

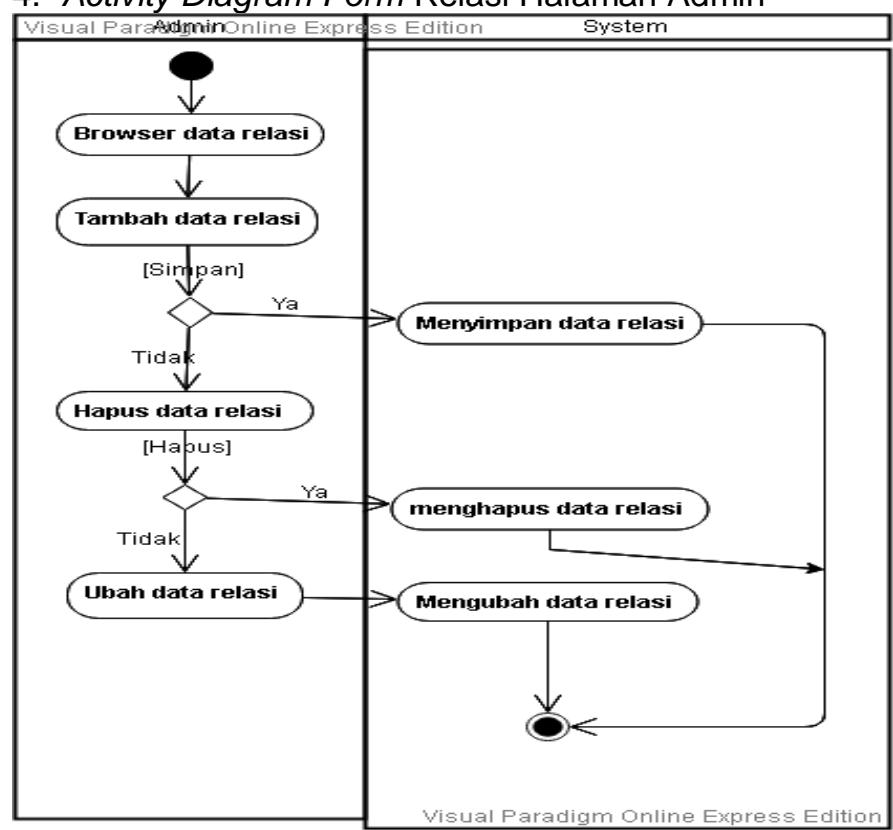

Gambar 11. Activity Diagram Form Relasi
5. Activity Diagram form Solusi

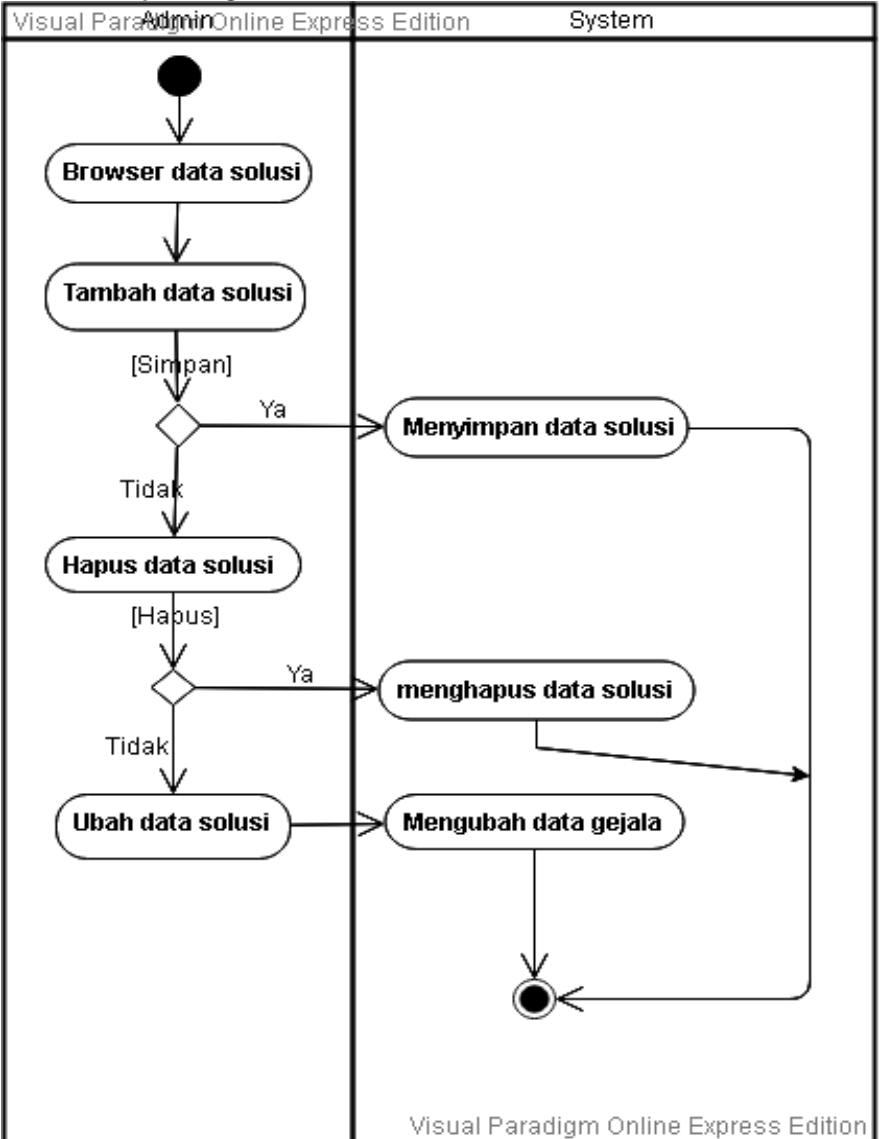

Gambar 12. Activity Diagram form Solusi Halaman Admin

6. Activity Diagram Data Kamus Otomotif Halaman Admin

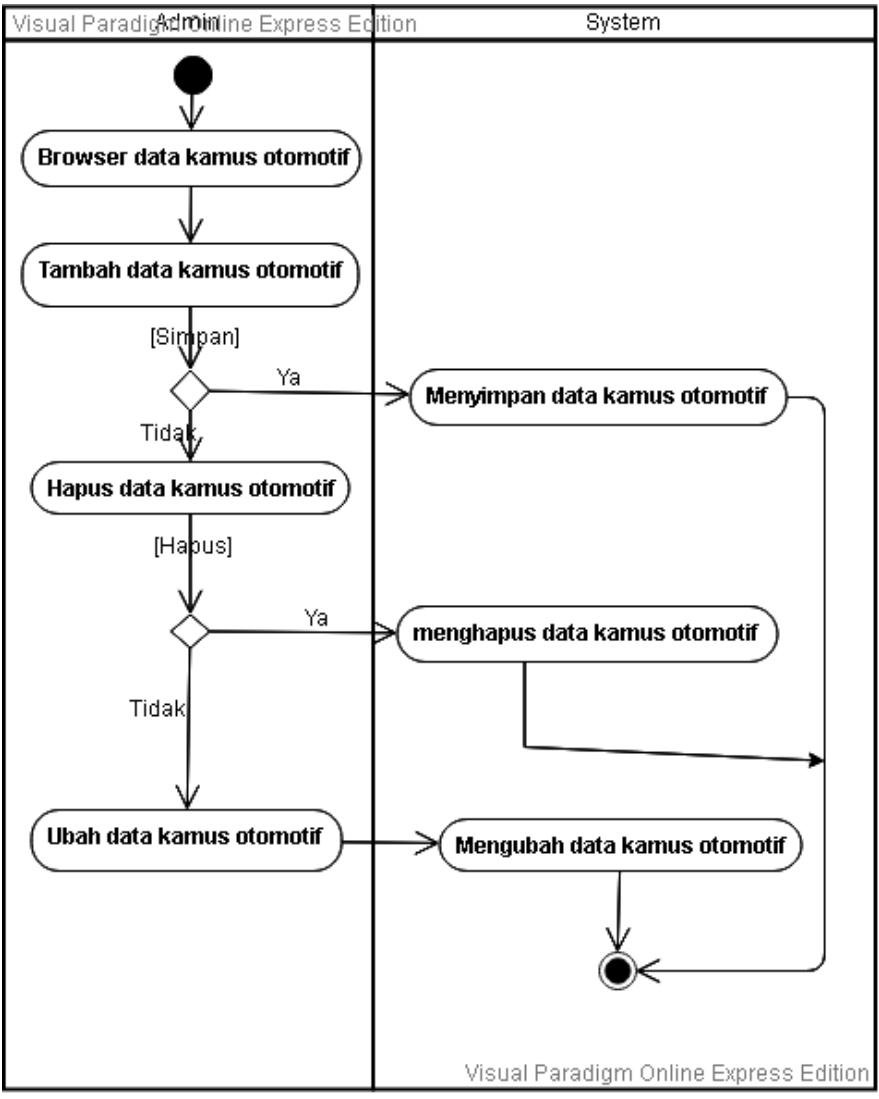

Gambar 13. Activity Diagram data kamus otomotif Halaman Admin 
7. Activity Diagram Data Admin

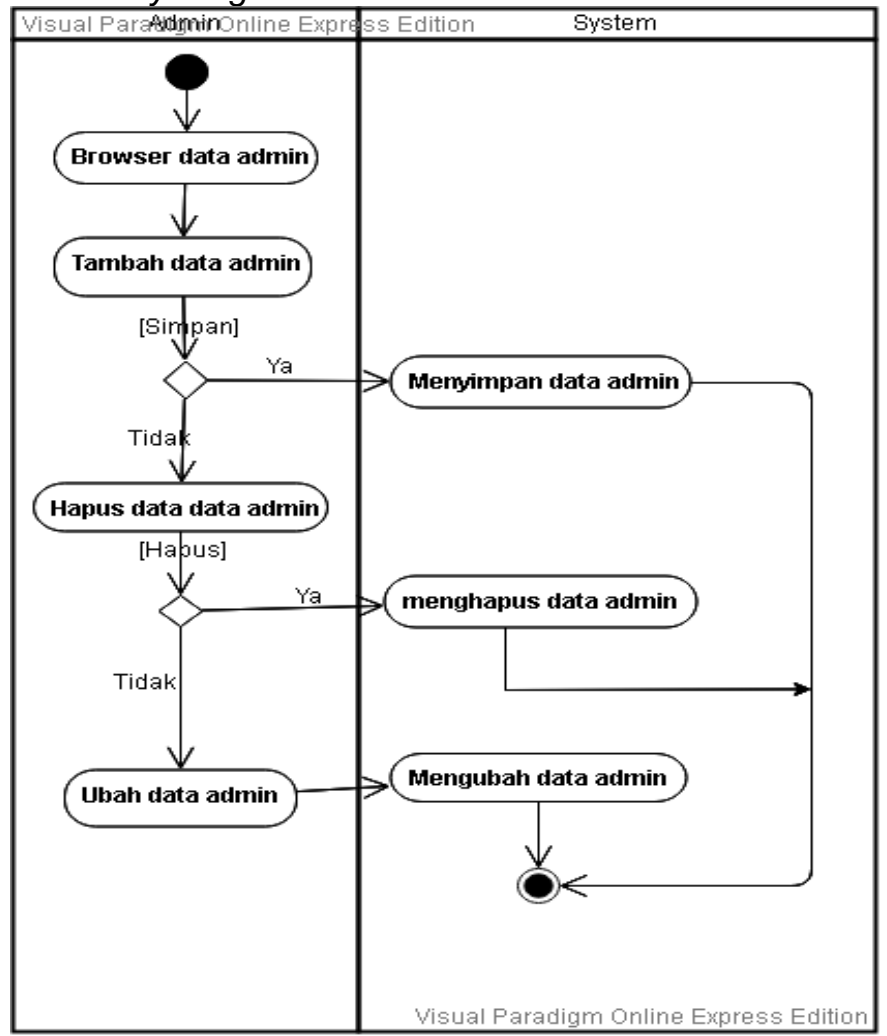

Gambar 14. Activity Diagram Data Admin

8. Activity Diagram Data Histori pengunjung

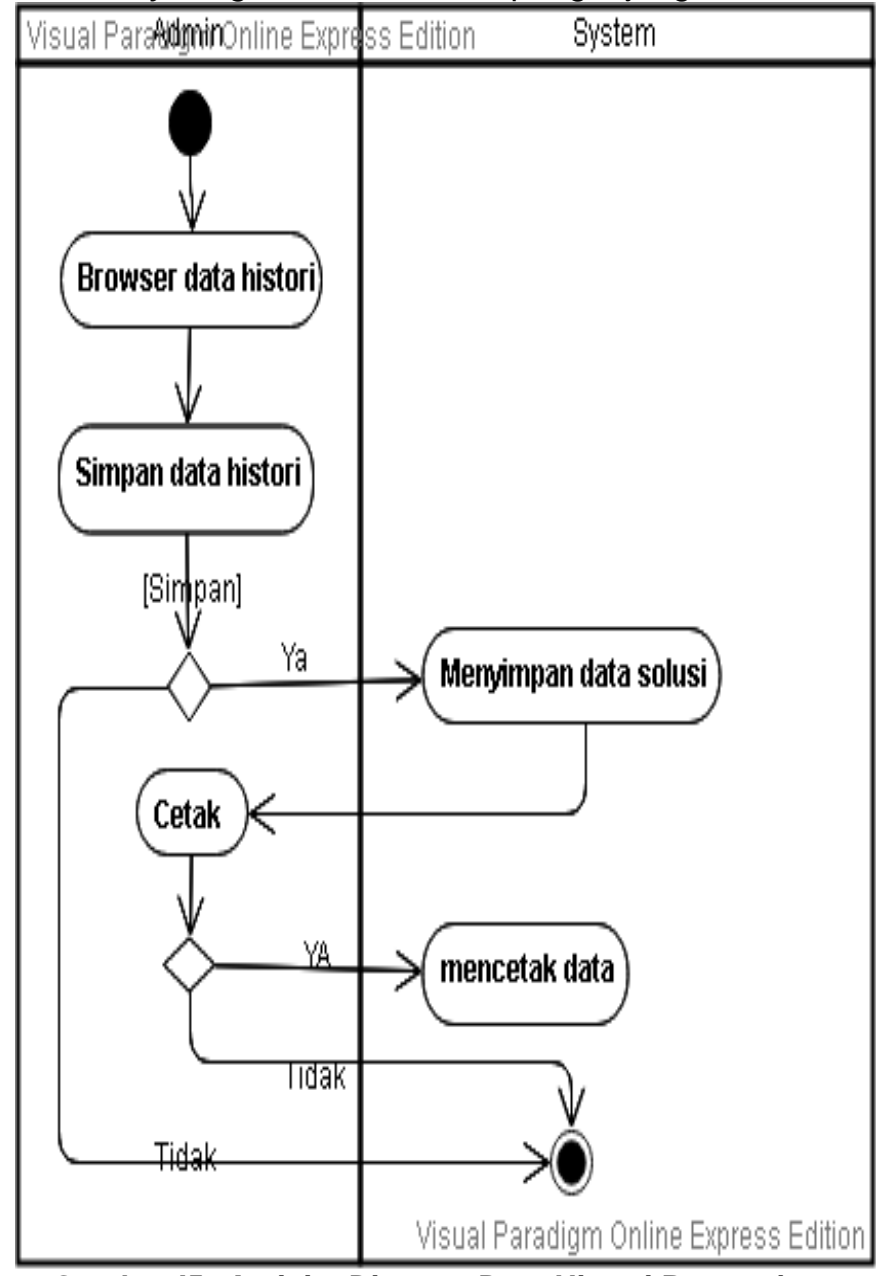

Gambar I5. Activity Diagram Data Histori Pengunjung

\section{Rancangan Prototype}

1. Halamam Utama User

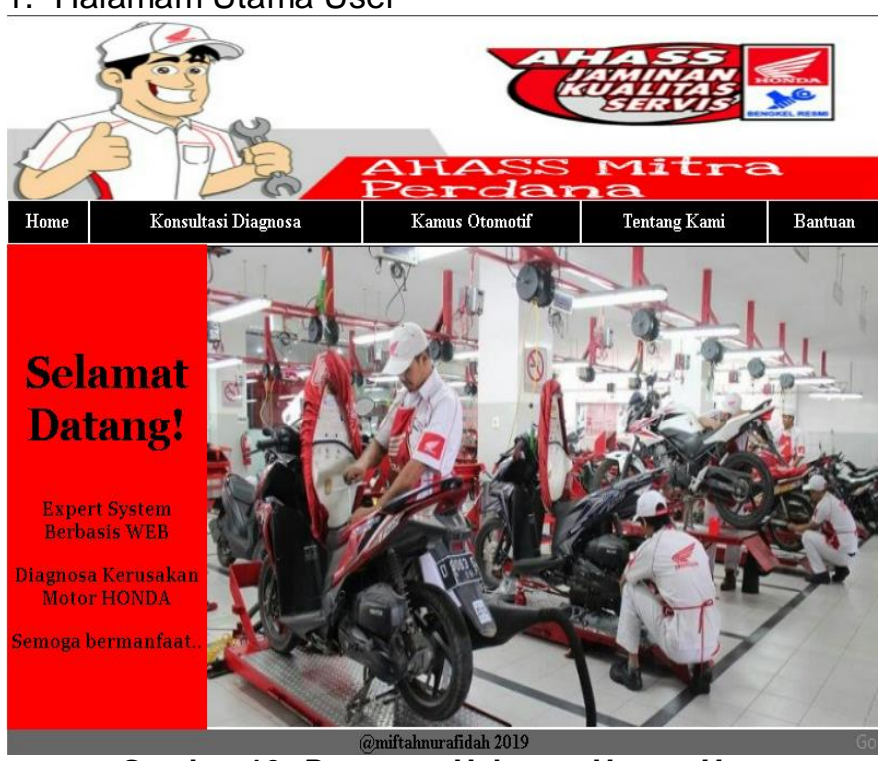

Gambar 16. Prototype Halaman Utama User

2. Halaman Login User
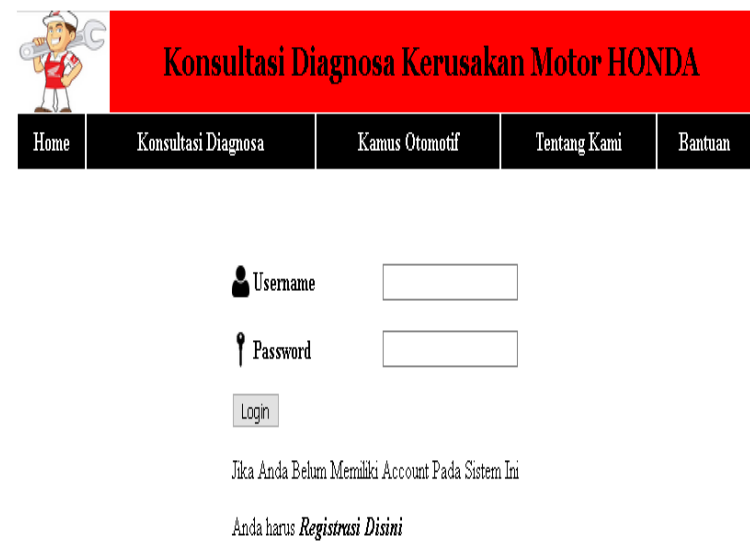

\section{(omiftahuraridah 2019}

\section{Gambar 17 Rancangan Prototype Form Login User}

3. Halaman Konsultasi Diagnosa

\begin{tabular}{c|c|c|c|c}
\hline \multicolumn{5}{c}{ Konsultasi Diagnosa Kerusakan Motor HONDA } \\
\hline Home & Konsultasidiagnosa & Kamus Otomotf & TertangKami & Bartuan
\end{tabular}

\section{PERTANYAAN}

Apakah mesin motor berputar tetapi tidak mau hidup?

$$
\text { O YA }
$$

Gambar 18. Rancangan Prototype Form Komsultasi Diagnosa User 


\section{Proses Hasil Diagnosa}

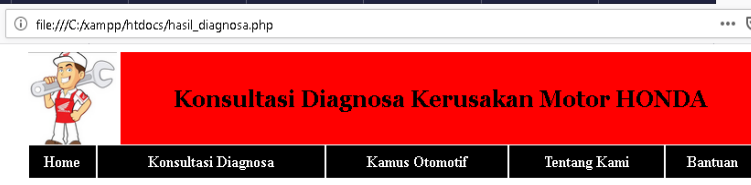

HASI DIAGNOSA KERUSAKAN

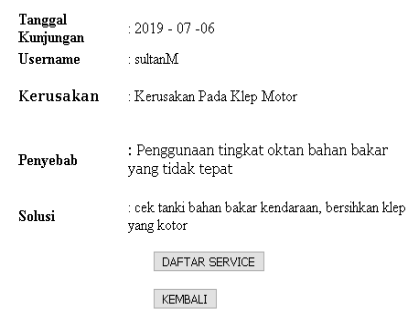

Gambar 19. Rancangan Prototype Halaman Utama User

5. Halaman Daftar Service

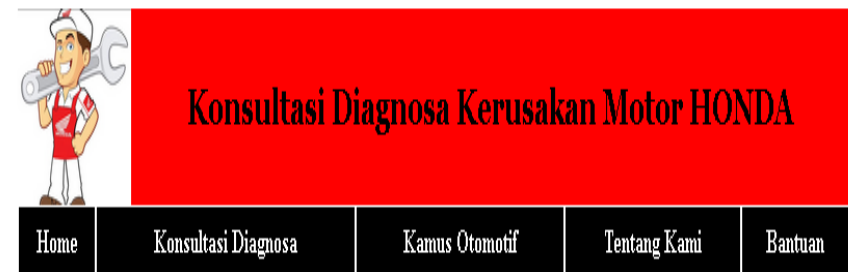

DAFTAR SERVICE KENDARAAN

Usemame
Nomor Kendaraan
Tanggal Service

Simpan Batal

Qcoppynght MiftahNurAfidah 2019

Gambar 20. Rancangan Prototype Form Daftar Service User

6. Halaman Login Admin

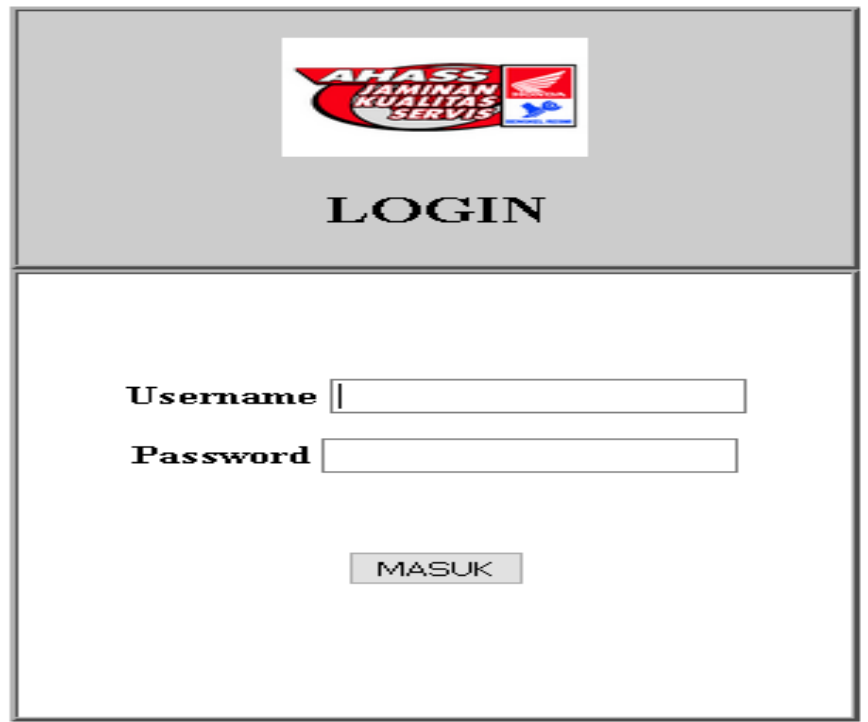

Gambar 21. Rancangan Prototype Halaman Login Admin
7. Menu Histori Pengunjung

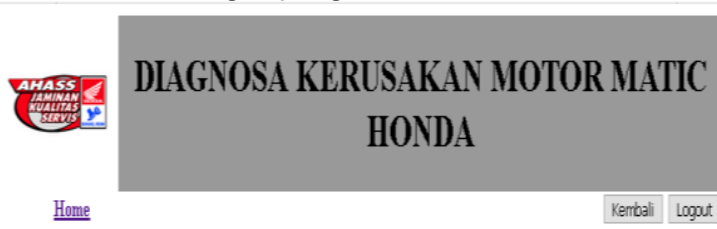

HISTORI KONSULTASI

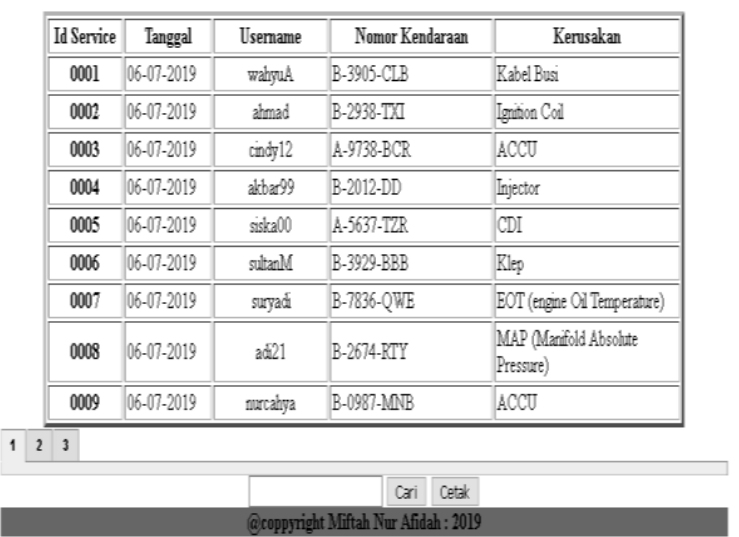

Gambar 22. Rancangan Prototype Form Histori Daftar Service User

\section{Class Model / Class Diagram}
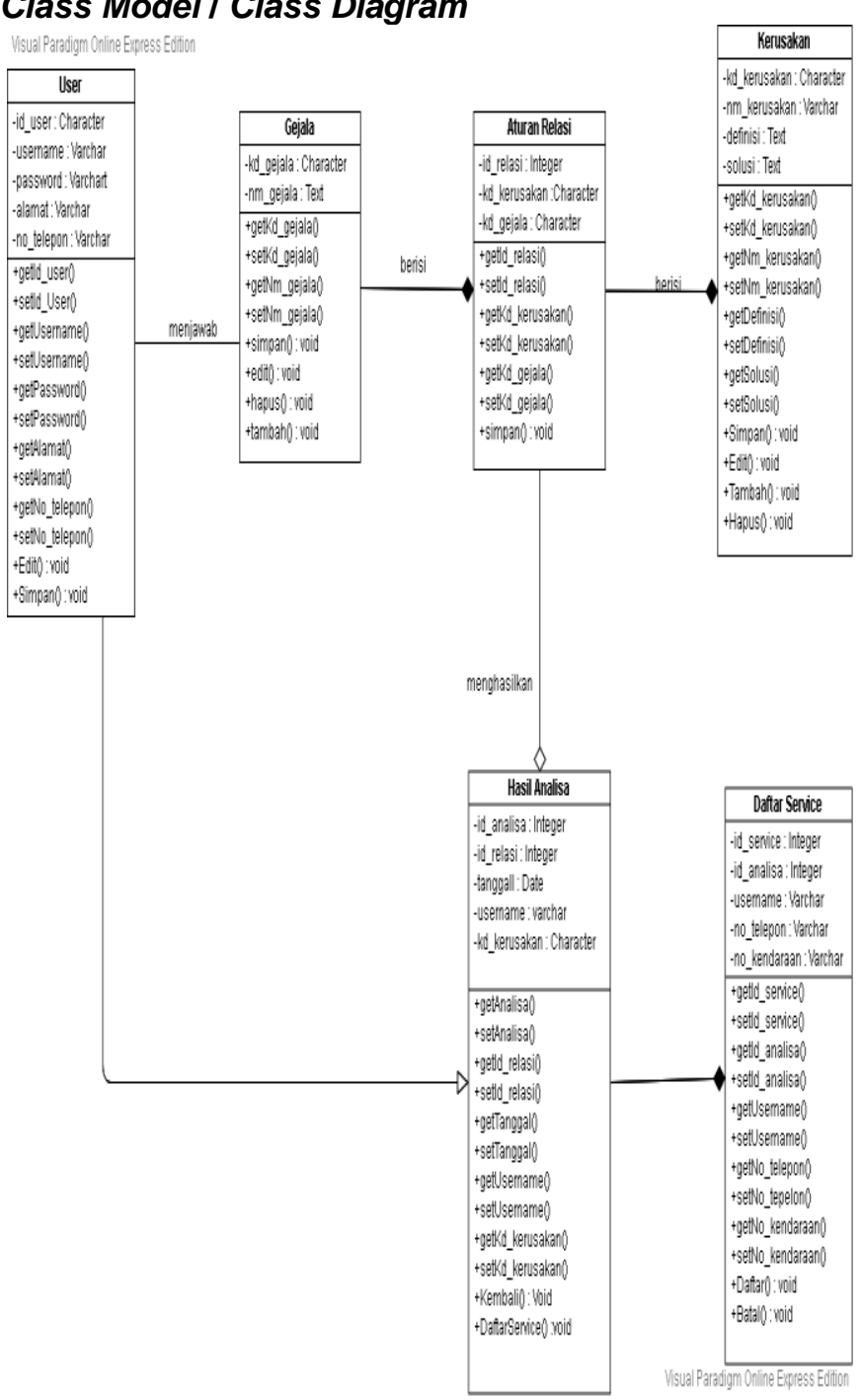

Gambar 23. Class Diagram

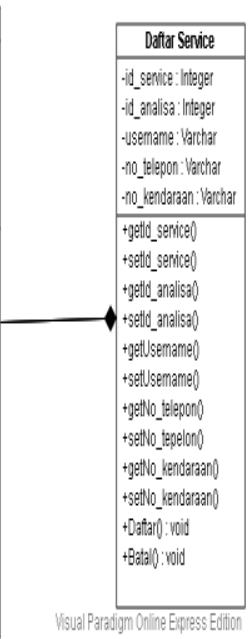




\section{Sequence Diagram}

1. Sequence Diagram Halaman Login User

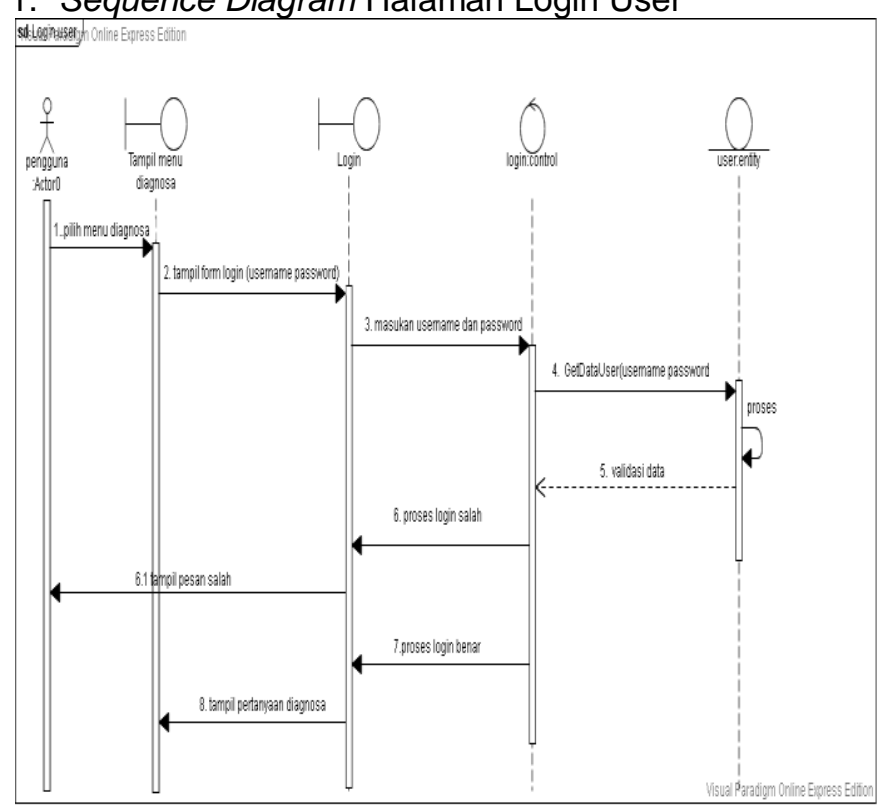

Gambar 24. Sequence Diagram Login User

2. Sequence Diagram Halaman Konsultasi Diagnosa

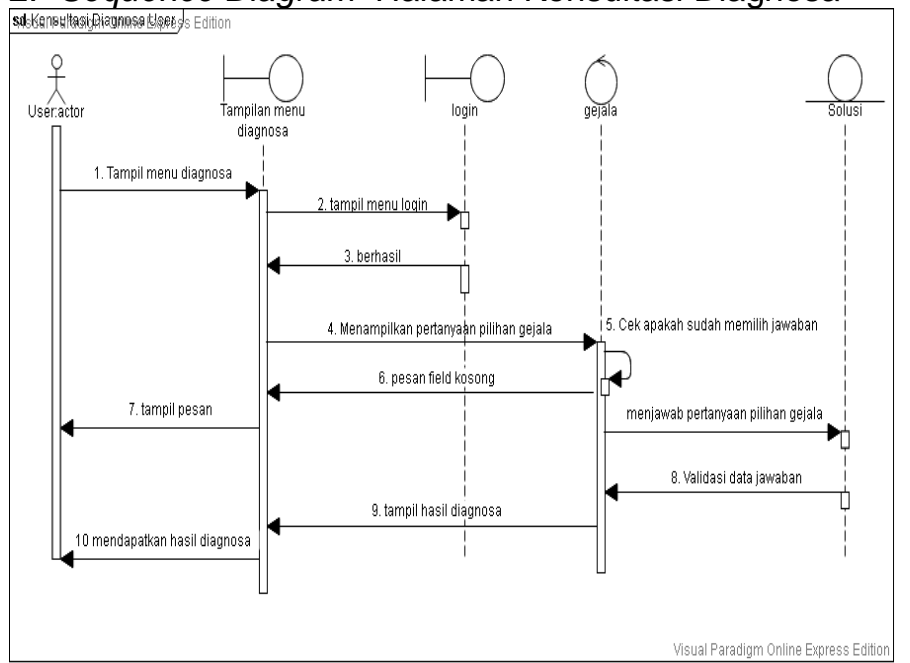

Gambar 25. Sequence Diagram Konsultasi Diagnosa

3. Sequence Diagram Login Admin

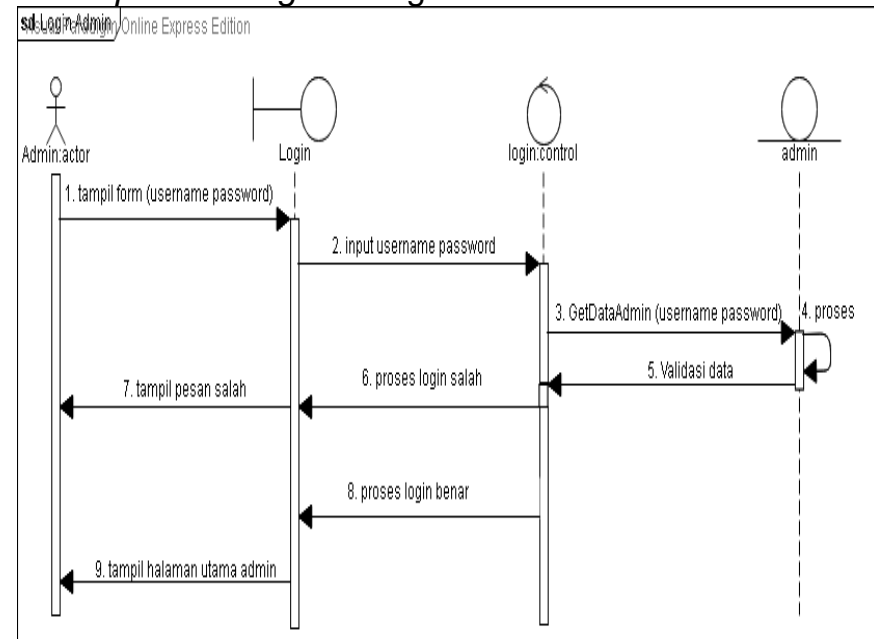

Gambar 26. Sequence Diagram Login Admin

\section{Sequence Diagram Halaman Admin}

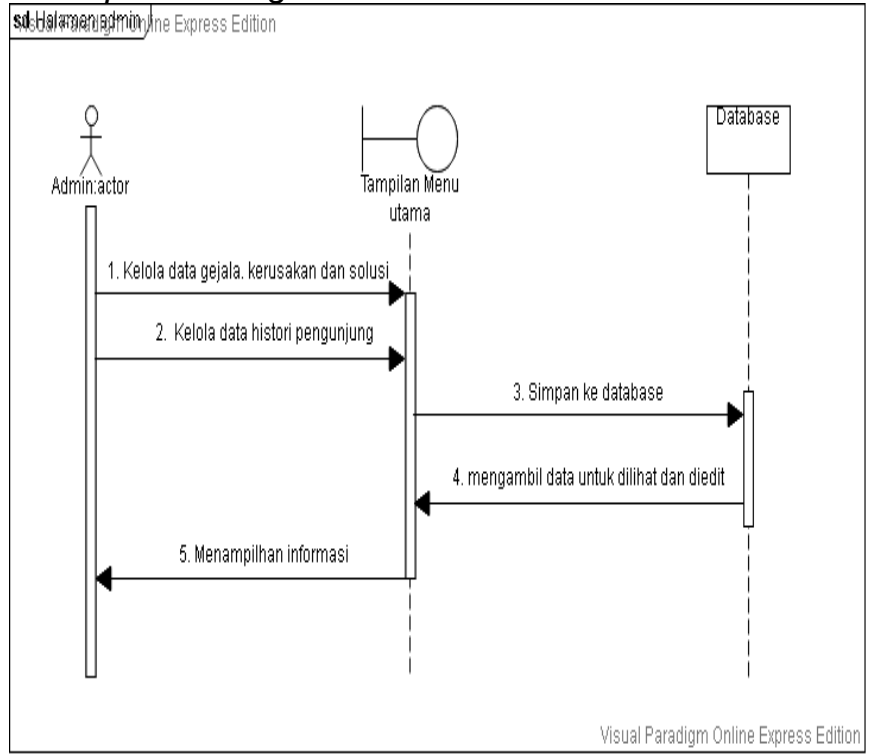

Gambar 27 Sequence Diagram Halaman Admin

\section{SIMPULAN}

Berdasarkan hasil rancangan sistem pakar diagnosis kerusakan pada mesin sepeda motor transmisi automatic dengan metode forward chaining, maka dapat diambil kesimpulan bahwa sistem pakar tersebut dapat digunakan sebagai penambah pengetahuan tentang mesin sepeda motor matic dari gejala-gejala yang dialami, memudahkan pengguna yang kurang memahami mesin motor, sehingga dapat tepat dalam menangani kerusakan yang ada, Proses diagnosis yang dilakukan melalui aplikasi dapat dilakukan dengan cepat sehingga memangkas waktu yang sebelumnya banyak terbuang di bengkel dan aplikasi ini dirancang dengan tampilan yang user friendly untuk memudahkan user dalam pengoperasiannya.

\section{DAFTAR PUSTAKA}

A.S, R., \& M, S. (2018). Rekayasa Perangkat Lunak. In Informatika Bandung

Achmad, S. (2016). Pemrograman Web dengan PHP dan MySQL. Kom Universitas Budi Luhur.

Anhar ST. (2010). Panduan Menguasai PHP dan Mysql Secara Otodidak. In Www.Duniailkom.Com.

Khaeruzzaman, Y. (2018). Sistem Pakar Diagnosa Kerusakan Sepeda Motor Bebek Berbasis Android. Sistem Pakar Diagnosa Kerusakan Sepeda Motor Bebek Berbasis Android, 52-70.

Kusrini. (2006a). Sistem Pakar, Teori dan Aplikasi (1st ed.; F. S. Suryantoro, ed.). Yogyakarta: ANDI.

Kusrini, M. ko. (2006b). "Sistem Pakar Teori dan Aplikasi." In Andi.

Munawar. (2005). Pemodelan Visual Dengan UML. Yogyakarta: Graha IImu.

Palit, R. V, Rindengan, Y. D. Y., \& Lumenta, A. S. M. (2015). Rancangan Sistem Informasi Keuangan Berbasis Web Di Jemaat GMIM Bukit Moria Malalayang. E-Journal Teknik Elektro Dan Komputer Vol, 4(7), 1-7.

Rahmayu, M. (2015). RANCANG BANGUN SISTEM INFORMASI NILAI UJIAN SISWA SMP NEGERI 3 BUMIAYU BERBASIS WEB. JURNAL 
KHATULISTIWA INFORMATIKA, 3(2), 10-17.

https://doi.org/10.1145/3132847.3132886

Ramadhan, A. (2007). Seri Pelajaran Komputer Internet dan Aplikasinya (2nd ed.). Jakarta: Pt Elex Media Komoputindo. 